\title{
A Review on Performance and Emission Analysis of Different Vegetable Oil as Biodiesel for CI Engine
}

\author{
Rupesh J. Yadav ${ }^{\dagger *}$, Prashant K. Kurve ${ }^{\ddagger}$ and Pooja J. Pawar ${ }^{\dagger}$ \\ †Department of Mechanical Engineering, MIT College of Engineering, Pune-411038, India
}

Accepted 02 March 2016, Available online 15 March 2016, Special Issue-4 (March 2016)

\begin{abstract}
Energy demand is increasing due to every increasing number of vehicles on the road by every day. Alternative fuels should be easily available, environment-friendly and techno-economically competitive. One of such fuels is triglycerides (vegetable oils/animal fats) and their derivatives. Since India is not self-sufficient in edible oil production, some non-edible oil seeds available in the country are required to be tapped for biodiesel production. With the abundance of forest and plant based non-edible oils being available in our country. Many researchers had carried out an investigation on biodiesel with Rice bran oil, Pongamia (Karanja), Jatropha curcas (Jatropha), Madhuca longifolia (Mahua Seed), Shorearobusta (Sal), Azadirachtaindica A. Juss (Neem) and Heveabrasiliensis (Rubber), etc. The aim of the paper is to review a performance and emission analysis of different vegetable oils as a biodiesel. In this paper, the comparative study of different biodiesel according to their cost carried out.
\end{abstract}

Keywords: Biofuel, Transesterification, Viscosity, Flash Point, Exhaust Temperature, Cetane Number, Calorific Value.

\section{Introduction}

Energy is an essential and vital input for economic activity. Building a strong base of energy resources is a pre-requisite for the sustainable economic and social development of a country. Indiscriminate extraction and increased consumption of fossil fuels have led to the reduction in underground-based carbon resources and release harmful emissions which are the main reason for global warming and ozone layer depletion. Biomass-derived vegetable oils are quite promising alternative fuels for agricultural diesel engines. Use of biodiesel in diesel engines leads to slightly inferior performance and higher smoke emissions due to their high viscosity (Sarayanan, et al, 2015).

Diesel fuel has an essential function in the industrial economy of a developing country and used for transport of industrial and the agricultural goods and operation of diesel tractors and pump sets in agricultural sector. The requirement of petrol diesel in India is expected to grow from 39.815 MMT in 2001-02 to 90 MMT in 2014-15 (Kumar, et al, 2013). The domestic supply of crude oil will satisfy only about $22 \%$ of the demand and the rest will have to be met from imported crude. This has stimulated recent interest in alternative sources to replace petroleumbased fuels. One of the alternative fuels, biodiesel obtained from vegetable oils holds good promises as an eco-friendly alternative to diesel fuel. Vegetable oil is a

*Corresponding author: Rupesh J. Yadav promising alternative fuel for $\mathrm{CI}$ engine because it is renewable, environment-friendly and can be produced in rural areas. The use of non-edible vegetable oils compared to edible oils is very significant in developing countries because of the tremendous demand for edible oils in the food supply and they are too expensive to be used as fuel at present. There has been renewed interest in the use of madhuca longifolia oil for making biodiesel because it is less polluting and renewable. It is biodegradable and non-toxic Worldwide biodiesel production is mainly from edible oils such as soybean, peanut, coconut, sunflower and canola oils (Kumar, et al, 2013).

\section{Biodiesel}

Biodiesel is produced by mixing vegetable or animal oil with a small quantity of methanol in a process known as esterification. Potential fuel crops include rice bran oil, rapeseed oil, soybean oil, and palm oil. They are used also as vegetable oils. In northern Europe oil seed rape is the most appropriate crop for the climatic conditions but requires intensive agricultural practices, pesticides and fertilizers. There are some adverse impacts on vulnerable farm land habitats and bird species (Hansen, et al, 1997).

Total European bio-diesel output in 2008 was 700,000 tones, with half the total production coming from France, followed by Austria, Germany, Italy, Spain and Sweden. This still represents only $6 \%$ of world production. A draft European specification for bio- 
diesel has recently been developed, and production targets have been set to 5 million tons by 2006 and 8.3 million tons by 2010, in order to reduce greenhouse and air polluting gas emissions. Zero fuel duty rates in Germany, Austria, Italy and Spain and a variable duty regime in France may further encourage production of crops. Current diesel engines can operate with using $100 \%$ biodiesel. Emissions depend on the type of vehicle and fuel specification, but there are few air quality benefits relative to conventional diesel. Biodiesel is non-toxic and biodegradable, making it suitable for use on inland waterways and other sensitive marine environments. Like bio-ethanol, climate change benefits ultimately depend on how the crop is produced (Gashaw, et al, 2014).

Kumara, et al, (2013) States that the objective is an experimental investigation has been conducted on single cylinder diesel engine fueled with blends of Mahua and diesel. Five concentrations of biodiesel are taken for investigation and the engine performance characteristic has been studied under different loading conditions. The biodiesel with a concentration of $20 \%$ is found suitable for all blends of biodiesel and pure diesel.

Saravanan, et al, (2015) states his objective to the research was examine the characteristics of Sapotaceae oil and its blends. Sapotaceae butyl ester is derived through transesterification process in the presence of two different processes such as pre-process and postprocess. A single cylinder, water cooled, four stroke diesel engine was used for this work. The following fuels were tested such as diesel, B10, B20, B30, PB10, PB20, PB30 (where PB are denoted as post process ) observe their properties and performance. To observe the results of diesel, Sapotaceae oil butyl esters and their blends with diesel by volume were compared. In this process, the yield in preprocessing is $60 \%$ per liter and $75 \%$ in post process.

Hirkude, et al, (2012) in his paper discusses the results of investigations carried out on a single cylinder, four-stroke, DI diesel engine operated on methyl esters of waste fried oil blended with mineral diesel. The performance of the engine with diesel was considered as the baseline data. The performance parameters for different WFOME blends were found to be very close to diesel and the emission characteristics of engine improved significantly. At rated output, brake thermal efficiency of blend B50 (50\% biodiesel $+50 \%$ diesel) found $6.5 \%$ lower than that of diesel. For B50, brake specific consumption observed was $6.89 \%$ higher than that of diesel. $\mathrm{CO}$ emissions were reduced by $21-45 \%$ for different blends. The particulate matters were lower by $23-47 \%$.

Jo-Han, et al, (2012) states his objective to evaluate the suitability of biodiesel for on-road usage based on the engine-out responses of a light-duty diesel engine. Palm methyl ester (PME) was the biodiesel fuel used. The effects of engine speed and load over the entire operational range of engine performance and pollutant emissions when fuelled with neat PME (B100) and a B50 PME-diesel blend were identified.
Ozsezen, et al, (2009) states his objective to evaluate performance and combustion characteristics of a (DI) diesel engine fuelled with biodiesels such as a waste (frying) palm oil methyl ester (WPOME) and canola oil methyl ester (COME). In order to determine the performance and combustion characteristics, the experiments were conducted at the constant engine speed mode (1500 rpm) under the full load condition of the engine. The BTE of WPOME and COME is 4\%, 7\% less than diesel and emission is near to diesel.

Lokanatham, et al, (2013) states objective to covers the various aspects of biodiesel fuel derived from jatropha curcas and pongamia pinnata. Concluded that both pongamia pinnata and jatropha curcus oils have substantial prospects as long-term substitutes for petrodiesel fuels. The 95\% petrodiesel and 5\% SVO of pongamia pinnata or jatropha curcus blend competed favorably with petrodiesel fuel and offer a reasonable substitute although blend of $85 \%$ diesel and 15\% SVO of pongamia pinnata or jatropha curcus can also be used without any significant loss in engine output and without any major operational difficulties.

\section{Sources and Availability}

\subsection{Mahua}

The Mahua trees are indigenous to India, grow even in draught-prone areas and are found abundantly in several parts of India. Seeds fallen are collected, and oil is extracted at village level expellers, few million tons of oil will be available for lighting lamps in a rural area. In some countries, Mahua oil is considered edible as it is used only for preparing ghee, but in our country, it has been considered as non-edible oil. Growing Mahua trees would also help in protecting the environment and benefit the farmers as well. It is the best substitute for kerosene. Since these are spread over a large area, the collection of seeds for Biodiesel manufacturer is not viable. A compact plantation can support a Biodiesel plant (Kumar, et al, 2013).

\subsection{Palm oil}

Also known as Dende Oil is an edible vegetable oil derived from the Mesocarp (reddish pulp) of the fruit of the oil palms. Palm oil is naturally reddish in colour because of high beta-carotene content. It is not to be confused with palm kernel oil derived from the kernel of the same fruit, or coconut oil derived from the kernel of the coconut palm (Cocos nucifera). The differences are in colour (raw palm kernel oil lacks carotenoids and is not red) and in saturated fat content. Palm mesocarp oil is $41 \%$ saturated, while palm kernel oil and coconut oils are $81 \%$ and $86 \%$ saturated respectively (Jo-Han, et al, 2012).

\subsection{Rapeseed}

It is also known as rape, oilseed rape, rapa, rappi, rapaseed, is a bright-yellow flowering member of the family Brassicaceae. The name derives from the Latin for turnip, rāpa or rāpum, and is first recorded in 
English at the end of the 14th century. Some botanists also include the closely related B. Campestris within B. Napus. The production of biodiesel has been steadily increasing in EU and USA to 15 million metric tons in 2010. Rapeseed oil is positioned to supply a good portion of the vegetable oils needed to produce that fuel. Every ton of rapeseed yields about $400 \mathrm{~kg}$ of oil. Rapeseed oil takes between 135 and 150 days to mature, with some varieties only taking 110 days (Hansen, et al, 1997).

\subsection{Soybean}

The soybean in the US also called the soya bean in Europe (Glycine max) is a species of legume native to East Asia, widely grown for its edible bean which has numerous uses. Soy vegetable oil is a product of processing the soybean crop. Soybeans produce significantly more protein per acre than most other uses of land. The oil is used in many industrial applications. The main producers of soy are the United States (36\%), Brazil (36\%), Argentina (18\%), China (5\%) and India (4\%). The beans contain significant amounts of phytic acid, alpha-linolenic acid, and isoflavones (Canaki, et al, 2003).

\subsection{Cottonseed}

By weight, cottonseed is $60 \%$ cotyledon, $32 \%$ coat and $8 \%$ embryonic root and shoot. These are $20 \%$ protein, $20 \%$ oil and $3.5 \%$ starch. The seeds are about $15 \%$ of the value of the crop. They are pressed to make oil and used as ruminant animal feed (Ranganathan, et al, 2012).

\section{Cost Analysis}

The price of oil is varying according to the region in the Indian context. Table 1 shows different types of vegetable oil prices that are available in the local market (Hirkude, et al, 2012), (Kumar, et al, 2013), (Ranganathan, et al, 2012). The price of waste fried oil and palm oil less than diesel so this oil may be as used as a substitute to the diesel.

Table 1 Different price of oils in India

\begin{tabular}{|c|c|c|}
\hline S. No & Oil Name & $\begin{array}{c}\text { Current Price In } \\
\text { India Rs Per Liter }\end{array}$ \\
\hline 1 & Diesel & 51.82 \\
\hline 2 & Mahua & 80 \\
\hline 3 & Waste Fried Oil & 24.30 \\
\hline 4 & Palm Oil & 46 \\
\hline 5 & Rapa Seed & 300 \\
\hline 6 & Soya bean & 64 \\
\hline 7 & Cotton Seed & 68 \\
\hline
\end{tabular}

\section{Fuel Properties}

Since biodiesel is produced from vegetable oils of varying origin and quality, the pure biodiesel must meet before being used as a pure fuel or being blended with conventional diesel fuels (Kumar, et al, 2013), (JoHan, et al, 2012), (Hansen, et al, 1997), (Canaki, et al, 2003), (Ranganathan, et al, 2012). Table 2 shows various properties which define the quality of biodiesel below. From this table shows that the kinematic viscosity and flash point is more than the diesel.

Table 2 Comparative analysis of properties of different biodiesel with conventional diesel

\begin{tabular}{|c|c|c|c|c|c|c|}
\hline $\begin{array}{l}\dot{z} \\
\dot{n}\end{array}$ & $\begin{array}{l}\frac{\Xi}{\Xi} \\
\stackrel{\Xi}{0} \\
\overline{0}\end{array}$ & 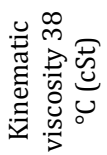 & 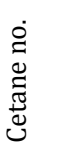 & 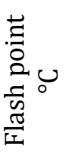 & 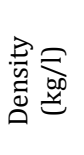 & 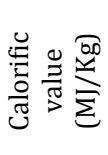 \\
\hline 1 & Diesel & 3.06 & 50 & 76 & 0.855 & 43.8 \\
\hline 2 & Mahua & 33.6 & 34 & 238 & 0.867 & 36.22 \\
\hline 3 & $\begin{array}{c}\text { Waste } \\
\text { fried oil }\end{array}$ & 31 & & 180 & 0.915 & 31 \\
\hline 4 & Palm oil & 39.6 & 42 & 267 & 0.981 & 33.5 \\
\hline 5 & $\begin{array}{l}\text { Rape } \\
\text { seed }\end{array}$ & 37 & 38 & 246 & 0.911 & 39.7 \\
\hline 6 & Soybean & 32.6 & 38 & 254 & 0.913 & 37.9 \\
\hline 7 & $\begin{array}{l}\text { Cotton } \\
\text { seed }\end{array}$ & 33.5 & 42 & 234 & 0.914 & 39.5 \\
\hline
\end{tabular}

\section{Comparison of Performance Characteristics}

The engine used for the testing purpose is four strokes, single cylinder engine in which different blends of biodiesel is tested. In this engine, one of the parameters is kept constant such as if take pressure is constant then the load is varied vice versa. While performing different blends testing a little change is made outside the engine such injection of biodiesel. The performance characteristics calculation includes brake specific fuel consumption (kg/bhp-hr), brake thermal efficiency (\%), etc. In this paper, different biodiesel with their B20 blends compared with performance characteristics which are shown in table 3. For this calculation, researchers kept injection pressure constant and a load is varied.

Table 3 Performance characteristics different biodiesel with their B20 blends

\begin{tabular}{|c|c|c|c|}
\hline $\begin{array}{c}\text { S. } \\
\text { No }\end{array}$ & Oil name & $\begin{array}{c}\text { Brake specific } \\
\text { fuel } \\
\text { consumption } \\
\text { (kg/bhp-hr) }\end{array}$ & $\begin{array}{c}\text { Brake thermal } \\
\text { efficiency \% }\end{array}$ \\
\hline 1 & Diesel & & 36.96 \\
\hline 2 & Mahua & 0.3 & 35 \\
\hline 3 & Waste fried oil & 0.35 & 28 \\
\hline 4 & Palm oil & 0.29 & 30 \\
\hline 5 & Rape seed & 0.3 & 40 \\
\hline 6 & Soya bean & 0.31 & 38 \\
\hline 7 & Cotton seed & 0.2 & 35 \\
\hline
\end{tabular}


The fig. 1 shows the comparison of a performance characteristic of different biodiesel with B20 blends. In this graph the brake thermal efficiency (BTE) of cotton seed and mahua oil biodiesel is nearly same to the diesel and the BTE of rapeseed is among the highest in all biodiesels. The brake specific fuel consumption (BSFC) of waste fried oil is highest in this class. Mahua and palm biodiesel is nearly equal to the diesel (Kumar, et al, 2013), (Jo-Han, et al, 2012), (Hansen, et al, 1997), (Canaki, et al, 2003), (Ranganathan, et al, 2012).

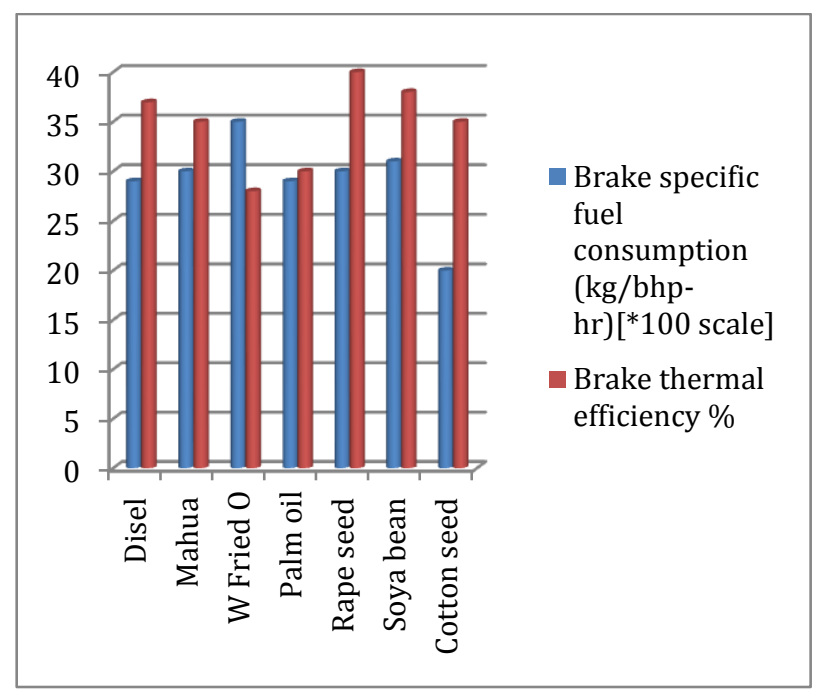

Fig.1 Comparison of performance characteristic different biodiesel with their B20 blends

\section{Comparison of Emission Characteristics}

The emission analysis of different blends of biodiesels done by measuring exhaust temperature, $\mathrm{CO}, \mathrm{HC}, \mathrm{NOx}$, particulate matter and smoke opacity. This measurement is done by a temperature sensor, five channel fuel gas analyzer, smoke opacity meter, etc. Table 4 shows different emission property of B20 blend of biodiesel. For this calculation, researchers kept injection pressure constant and the load is varied.

Table 4 Emission characteristic different biodiesel with their B20 blend

\begin{tabular}{|c|c|c|c|c|c|}
\hline $\begin{array}{c}\text { S. } \\
\text { No }\end{array}$ & $\begin{array}{c}\text { Oil } \\
\text { name }\end{array}$ & $\begin{array}{c}\text { Exhaust } \\
\text { temperature } \\
{ }^{\circ} \mathrm{C}\end{array}$ & $\begin{array}{c}\text { CO } \\
(\mathrm{ppm})\end{array}$ & $\begin{array}{c}\text { NOx } \\
(\mathrm{ppm})\end{array}$ & $\begin{array}{c}\text { Particulate } \\
\text { matter } \\
(\mathrm{ppm})\end{array}$ \\
\hline 1 & Diesel & 291 & 821 & 820 & 0.05 \\
\hline 2 & Mahua & 334 & 557 & 950 & 0.04 \\
\hline 3 & WF0 & 297 & 430 & 824 & 0.007 \\
\hline 4 & $\begin{array}{c}\text { Palm } \\
\text { oil }\end{array}$ & 385 & 500 & 1300 & 0.02 \\
\hline 5 & $\begin{array}{c}\text { Rape } \\
\text { seed }\end{array}$ & 425 & 975 & 952 & 0.04 \\
\hline 6 & $\begin{array}{c}\text { Soya } \\
\text { bean }\end{array}$ & 345 & 802 & 835 & 0.02 \\
\hline 7 & $\begin{array}{c}\text { Cotton } \\
\text { seed }\end{array}$ & 340 & 835 & 825 & 0.04 \\
\hline
\end{tabular}

Fig. 2 shows a comparison of different biodiesel with their B20 blend in emission characteristics. In this comparison, NOx emission (ppm) of palm oil is highest and waste fried oil, soybean oil, cottonseed biodiesel had nearly same NOx emission as diesel. Exhaust temperature $\left({ }^{\circ} \mathrm{C}\right)$ of rapeseed is more than any other and exhaust temperature of waste fried oil is as same as diesel. CO (ppm) emission of rapeseed oil is highest and soyabean oil and cotton seed oil has nearly same CO emission as diesel. Particulate matter (pm) is measured in ppm. Rapeseed oil pm emission is highest and waste fried oil pm emission is same as diesel (Kumar, et al, 2013), (Jo-Han, et al, 2012), (Hansen, et al, 1997), (Canaki, et al, 2003), (Ranganathan, et al, 2012).

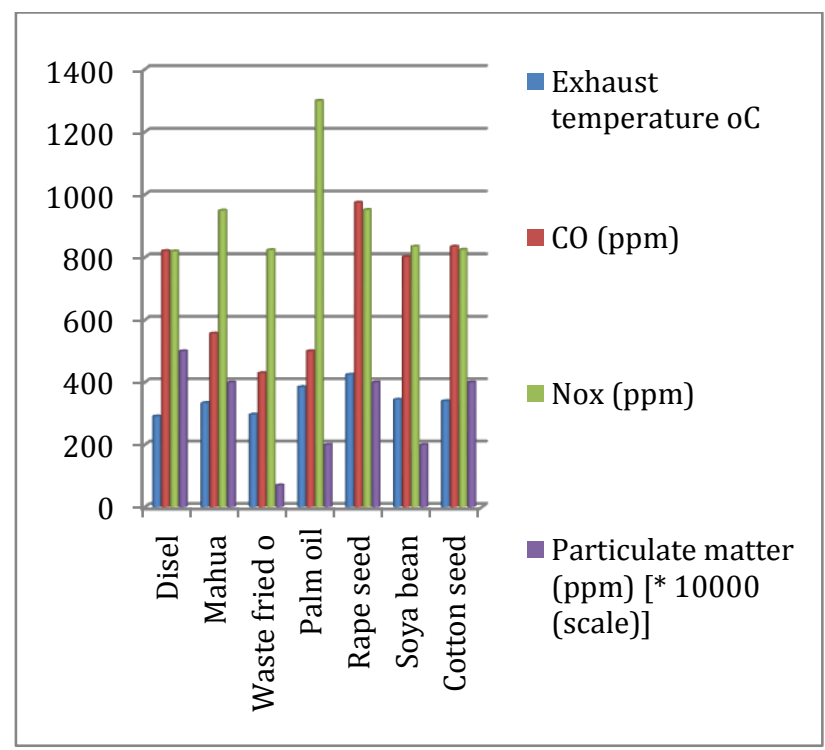

Fig.2 Comparison of emission characteristic different biodiesel with their B20 blends

\section{Conclusions}

Biodiesel produced from vegetable oil or animal fats by transesterification with alcohol like methanol and ethanol is recommended for use as a substitute for petroleum-based diesel mainly because biodiesel is an oxygenated, renewable, biodegradable and environment-friendly bio-fuel. From this paper concluding remarks are.

1) The results are shown in the different paper that on engine performance and emission characteristics when fuelled with the biodiesel blends such as mahua, waste fried oil, palm oil, rapeseed oil, cottonseed oil and soybean oil is compared to that when fuelled with petroleum diesel.

2) B20 blend is suitable and had performance and emission characteristics near to the diesel.

3) $\mathrm{CO}, \mathrm{CO} 2, \mathrm{HC}$ emission for the biodiesel blends is lower than that of the diesel fuel.

4) NOx emission for the biodiesel blends is higher than that of the diesel fuel.

5) The price of biodiesel is higher but some of them are low cost so there is scope to increase their production in our country. 
6) Edible vegetable oil is used mostly so chances to a hike of price of edible oil because they are used in food industry. So there is scope to a search number of non-edible oil and increase their production.

\section{References}

G. Kumar and A. Kumar, (2013) Engine Performance Characteristics of Diesel Engine Using Mahua Biodiesel as Fuel, International Journal of Current Engineering and Technology, Vol.3, pp.424-427.

R. Saravanan, P.N. Krishnan, R. Muralimanohar, (2015) Experimental and Performance Analysis of Four Stroke CI Engine on Sapotaceae Biodiesel And Its Blends, Journal of Chemical and Pharmaceutical Sciences JCHPS Special Issue 6, pp.215-218

J.B. Hirkude and A.S. Padalkar, (2012) Performance and Emission Analysis of a Compression Ignition Engine Operated on Waste Fried Oil Methyl Esters, Applied Energy, Vol.90, pp.68-72.

N. Jo-Han, N.H. Kiat, S. Gan, (2012) Characterisation of Engine-Out Responses from a Light-Duty Diesel Engine Fuelled with Palm Methyl Ester (PME), Applied Energy, Vol.90, pp.58-67.

A.N. Ozsezen, M. Canakci, A. Turkcan, C. Sayin, (2009) Performance and Combustion Characteristics of a DI Diesel Engine Fueled with Waste Palm Oil and Canola Oil Methyl Esters, Fuel, Vol.88, pp.629-636.

M. Canakci and G.H. Van, (2003) Comparison of Engine Performance and Emissions for Petroleum Diesel Fuel, Yellow Grease Biodiesel, and Soybean Oil Biodiesel, Trans ASAE, Vol.46(4), pp.937-44.

K.F. Hansen and M.G. Jensen, (1997) Chemical and Biological Characteristics of Exhaust Emissions from a DI Diesel Engine Fuelled with Rapeseed Oil Methyl Ester." SAE Paper no. 971689.

D.L. Purcell, B.T. McClure, J. McDonald, H.N. Basu, (1996) Transient Testing of Soy Methyl Ester Fuels in an Indirect Injection Compression Ignition Engine, J Am Oil Chem Soc, Vol.73(3), pp.381-8.
S. Murillo, J.L. Miguez, J. Porteiro, E. Granada, J.C. Moran, (2007) Performance and Exhaust Emissions in the Use of Biodiesel in Outboard Diesel Engines, Fuel, Vol.86, pp.1765-71.

M.J. Nye, T.W. Williamson, S. Deshpande, J.H. Schrader, W.H. Snively, C.L. French,(1983) Conversion of used frying oil to diesel fuel by transesterification: preliminary tests, $\mathrm{J} \mathrm{Am}$ Oil Chem Soc 1983, Vol.60(8), pp.1598-602.

T. Murayama, Y. Fujiwara, T. Noto, (2000) Evaluating waste vegetable oils as a diesel fuel, Proc Inst Mech Eng, Part D: J Automob Eng, Vol.214, pp.141-8.

R. Lokanatham and Ravindranath, (2013) Extraction and Use of Non-Edible Oils in Bio-Diesel Preparation with Performance and Emission Analysis on C.I. Engine, International Journal of Engineering Research and Development, Vol.6, Issue 5, pp. 35-45.

B.K. Barnwal and M.P. Sharma, (2004) Aspects of Biodiesel production from vegetable oils in India, Renewable and Sustainable Energy Reviews,Vol.21, pp.1-16.

A. Gashaw and A. Lakachew, (2014) Production of Biodiesel from Non Edible Oil and Its Properties, International Journal of Science and Technology, Vol. 3, pp.544 - 1562.

R.S. Antony, D.S. Robinson, R.C. Lee, (2011) Biodiesel Production from Jatropha Oil and Its Characterization, Research Journal of Chemical Sciences, Vol.1(1), pp.81-87.

W. Alnuami, A. Buthainah, C.J. Etti, L.I. Jassim, G.A. Gomes, (2014) Evaluation of Different Materials for Biodiesel Production, International Journal of Innovative Technology and Exploring Engineering, Vol.3(8), pp.1-8.

A. Siva Kumar, D. Maheswar, K.V. Reddy, (2009) Comparison of Diesel Engine Performance and Emissions from Neat and Transesterified Cotton Seed Oil, JJMIE, Vol.3, pp.45-51.

S.K. Ranganathan, A. Gandamwad, M. Bawankure, (2012) Performance Evaluation of C.I. Engine with Cotton Seed Oil,International Journal of Instrumentation, Control And Automation (IJICA) , Vol.1, Iss.3, pp.4-10.

M.A. Modi, T.M. Patel, G.P. Rathod,( 2014) Performance and Emission Analysis of Diesel Engine using palm seed oil and diesel blend, IOSR Journal of Mechanical and Civil Engineering (IOSR-JMCE), Vol.11, pp.29-33.

http://www.thealternative.in/lifestyle/biodiesel-the-futureof-sustainable-fuels/ 